\title{
Microbialite-like structures in Cladophora sp. (Ulvophyceae) mats from a subtropical Andean basin: ecological implications
}

\author{
Hugo R. Fernández ${ }^{1,2}$, Ana L. González Achem ${ }^{3,4}$, Marcela Correa ${ }^{1,5}$ \\ \& Virginia H. Albarracín $1,6,7$ \\ 1. Facultad de Ciencias Naturales e Instituto Miguel Lillo, UNT, Miguel Lillo 205. 4000 San Miguel de Tucumán, \\ Argentina; hrfe@csnat.unt.edu.ar \\ 2. IBN (UNT-CONICET), Horco Molle s/n. 4107 Yerba Buena. Tucumán, Argentina. \\ 3. INEDES (UNLu-CONICET). Ruta Nacional 5 y Avda. Constitución. 6700 Luján, Buenos Aires, Argentina; \\ anagonzalezachem@gmail.com \\ 4. Fundación Miguel Lillo, Instituto de Invertebrados, Miguel Lillo 251, T4000JFE-San Miguel de Tucumán, Argentina. \\ 5. Fundación Miguel Lillo, Instituto de Comportamiento Animal, Miguel Lillo 251, T4000JFE-San Miguel de Tucumán, \\ Argentina; mcorrea@lillo.org.ar \\ 6. PROIMI (CCT CONICET TUCUMAN), Av. Belgrano y Pasaje Caseros. 4000 San Miguel de Tucumán, Argentina; \\ cime@tucuman-conicet.gov.ar \\ 7. Centro Integral de Microscopía Electrónica (CIME, UNT -CCT CONICET TUCUMAN), Chacabuco 461, 4000 San \\ Miguel de Tucumán, Argentina.
}

Received 20-XII-2017. Corrected 20-IX-2018. Accepted 20-XI-2018.

\begin{abstract}
The solubility equilibrium of calcite is influenced by physicochemical, climatic and biological factors. Annual cycles of exceptionally prolonged drought, in conjunction with naturally occurring diffuse organic pollution, generate the unique conditions for the precipitation of lithified carbonate structures (microbialites). The aim of this article is to analyze the possible implications of calcite precipitation produced in mats of Cladophora sp. in an Andean subtropical basin, considering it is the first time this phenomenon is described for the region. We collected samples from selected sites at the Lules River Basin, in four sampling dates between the years 2003 and 2004, within a monitoring work of 15 years. Samples were analyzed using an electron microscope and X-ray diffraction analysis. We found that Gomphonema sp. attached to Cladophora sp. contributes to precipitation of calcite and formation of microbialite like structures, in the studied area. This work presents an initial discussion of the discovery of microbialites-like structures attached to Cladophora sp. mats in a subtropical Andean stream and the environmental conditions that lead to their production, as well as the possible ecological implications of these microbialites.
\end{abstract}

Key words: lithified carbonate; diatoms; epiphytes; climatic dry cycles.

Fernández, H. R., González Achem, A. L., Correa M., \& Albarracín, V. H. (2019). Microbialitelike structures in Cladophora sp. (Ulvophyceae) mats from a subtropical Andean basin: ecological implications. Revista de Biología Tropical, 67(1), 83-93.

Living benthic microbial communities (BMCs) include complex ecological clusters of photosynthetic prokaryotes, eukaryotic microalgae, and chemoautotrophic and chemoheterotrophic microbes (Burne \& Moore, 1987). Within BMCs, benthic algae are the primary producers in rivers and streams (Burne
\& Moore, 1987). The four major processes involved in the formation of calcareous microbialites are trapping and binding of detrital sedimentary particles, inorganic calcification, biologically influenced calcification, and skeletal calcification. Diatoms, as Gomphonema sp., participate specifically in the process of 
inorganic calcification (Burne \& Moore, 1987). Inorganic calcification is the most common calcification in rivers and streams, mainly environments with high alkalinity content. In these habitats, the loss of $\mathrm{CO}_{2}$ and consequent increase in $\mathrm{pH}$ is promoted by turbulence, increase in temperature or freezing. The $\mathrm{pH}$, which reflects the partitioning of the carbon species, is usually about 8.2 in air-equilibrated surface waters (Chafetz, Rush, \& Utech, 1991). Elevated $\mathrm{pH}$ in surface waters is mainly caused by intense primary production during periods with high concentrations of phytoplankton cells, e.g. towards the end of bloom periods. Intense photosynthetic activity can result in $\mathrm{pH}$ values as high as 9 or 10 (Trimborn et al., 2008).

The factors that interfere in the precipitation of calcite in rivers and streams are related to the increase of flow (for example by increasing precipitations or winds) or with the income of organic matter (OM), when this surpasses the biochemical demand for oxygen in relationship to $\mathrm{O}_{2}$ producing organisms present in the system (Kwong, Salas, Gutiérrez, \& Lopez, 2004).

The genus Cladophora (Ulvophyceae, Clorophyta) is one of the most important of the attached benthic algae as they tend to alter the conditions of the microhabitats they live into by modifying current, blocking sunlight, absorbing dissolved oxygen, collecting detritus and providing refuge for invertebrates (Dodds, 1991; Fernandez \& Reid, 2012). Cladophora is also an important substrate for epiphytic growth due to its ability to withstand the shear stress typical in the benthic regions of rivers (Dodds \& Gudder, 1992). In marine systems, Cladophora has been associated with lithified carbonated structures, where it has been found to form mixed communities with cyanobacteria (Dodds \& Gudder, 1992). In freshwater streams, Cladophora mats have also been described as associated with carbonate layers (Sandgren, Engevol, Neerhof, \& Ehlinger, 2004). The carbonate covers were noted in areas exposed to high illumination $\left(>1500 \mu \mathrm{E} \mathrm{m}^{-2} \mathrm{~s}^{-1}\right)$ and an intermediate flow rate (average $30 \mathrm{~cm} \mathrm{~s}^{-1}$ ).
Microbial biomass is the most important component of sediment deposits in alluvial plains, and calcium-bearing minerals compromise about $50 \%$ of known biominerals sediments (Weiner \& Dove, 2003). Nevertheless, the causes for the formation of these structures and the effects of calcification on Cladophora growth or photosynthetic rates are not well studied.

Microbialites are organosedimentary deposits formed from the interaction between BMCs and detrital or chemical sediments (Burne \& Moore, 1987). The interaction can take place in one of three different ways: I) film or veils, in which the BMC is dispersed throughout loosely consolidated detrital sediment; II) mats, which are cohesive BMC masses, formed around trapped and bound detrital sediment; III) indurated masses, typically composed of limestone, produced by mineralization of the BMC.

Most known microbialites are accreted by precipitated calcium carbonate and thus perform a key process in carbon cycling in continental aquatic systems (Weiner \& Dove, 2003; Dittrich \& Obst, 2004). This is especially important as the solubility equilibriums are complex in these systems and therefore present an important microbiological contribution. Microorganisms, cyanobacteria and several species of algae actively participate in processes of alteration and mineral transformation, as well as having a considerable influence on biogeochemical cycles (Romani \& Sabater, 1998; Dittrich \& Obst, 2004; Rolandi, Galindo, Fernandez, \& Hidalgo, 2011). Winsborough (2000) observed that diatoms are responsible for the majority of microbial carbonate formation, which includes the production of mucilage, an important prerequisite for carbonate precipitation in freshwater environments (Winsborough, 2000). Furthermore, biofilm or microbial mats, formed by diatoms and their extracellular polysaccharide secretions, are directly related with all carbonate precipitates, even in rapidly growing facies. This biofilm plays a central role in the precipitation, trapping, and binding of carbonate crystals, 
and its presence in ancient carbonates provides insights into their possible diagenetic pathways. The diatom Gomphonema Ehremberg (Bacillariophyceae) is conspicuous in karstwater stream biofilms as these diatoms exhibit calcite precipitation around their stalks (Winsborough \& Golubic, 1987).

In the subtropical mountain rivers of the Andean region of Argentina, the presence of nutrients in water bodies, as well as increased light exposure in the late winter and early spring, encourages the growth of Cladopho$r a$ between August to September (Fernandez, Romero, \& Domínguez, 2009). Hydrologic conditions, especially climatic factors such as seasonal rainfall, heavily affect benthic fauna (Mesa, Fernandez, \& Manzo, 2009). The monsoon pattern of precipitation heavily influences the habitat, biotic interactions, etc. (Fernandez et al., 2009). These cyclical fluctuations of precipitation can also influence the ionic concentration of soluble major ions in rivers by varying the solvent volume. This, coupled with the dissolution of certain types of rocks such as gypsum $\left(\mathrm{CaSO}_{4}\right)$, calcite $\left(\mathrm{CaCO}_{3}\right)$, etc., can lead to increased solute concentration during low flow of rivers, which has been found to affects some groups of invertebrates.

During a long-term research study (1998 2013) on benthic organisms at the Lules River Basin, province of Tucuman (NW Argentina), calcium micro-precipitates were observed within Cladophora mats growing in close relationship with the epiphytes community that inhabit the streams. This study describes the first microbialite-like structures observed within algal mats of Cladophora sp. in a subtropical region, and presents a hypothesis about their origins and formation. The aim of this article is to analyze the possible implications of calcite precipitation produced in mats of Cladophora sp. in an Andean subtropical basin, considering it is the first time this phenomena is described for the region.

\section{MATERIAL AND METHODS}

Study Area: Lules River Basin is located at Northwestern Argentina (Fig. 1a), and occupies an area of $1077 \mathrm{~km}^{2}$ (Garcia, 2010). It is an important drainage system for the subtropical mountain forests- "Yungas"- of the region (Fernandez et al., 2009; Mesa et al., 2009). The ecozone of Yungas is categorized by a monsoon regimen, in which $80 \%$ of the precipitation is concentrated in the aestival period, followed by dry winter and spring. Mesa (2006), Fernandez et al. (2009) and Garcia (2010) describe in further detail the geomorphometry and the environment of the area studied. Geological formations that underlie Lules River basin include all three rock types (metamorphic, igneous and sedimentary), the diversity and compositions of which have a direct influence on the geochemistry of the sediments and water (Fernandez \& Hidalgo, 2011). La Hoyada River station, coded LHR, 26 $6^{\circ} 46^{\prime} 10^{\prime}$ " $\mathrm{S} ; 65^{\circ} 28^{\prime} 20^{\prime \prime} \mathrm{W}$ (Fig. 1a), as well as the $4 \mathrm{~km}$ downstream, are comprised of terrace deposits and a floodplain made-up of sands, conglomerates and mud. Subsequently, the water passes through Rio Salí formation -characterized by siltstone, claystone, limestone and gypsumand continues $1 \mathrm{~km}$ further through La Yesera formation, which is comprised of conglomerates, conglomeratic sandstones and sandstones. Lules River then runs through Rio Loro formation, which is composed of sandstones and diamictites, including carbonate concretions, where Las Juntas River station, LJR, is located (26 51' 27' S \& 65 25'35' W, Fig. 1a).

The average annual flow volume and flow rate of the Lules River is $6.07 \mathrm{~m}^{3} \mathrm{~s}^{-1}$ with the average monthly flow fluctuating between 2.18 and $14.6 \mathrm{~m}^{3} \mathrm{~s}^{-1}$. The predominant major soluble ions in LHR are sodium/calcium and sulphate/ bicarbonate, changing to calcium/sodium and bicarbonate/sulphate in the area where the microbial mats with calcium precipitates were 


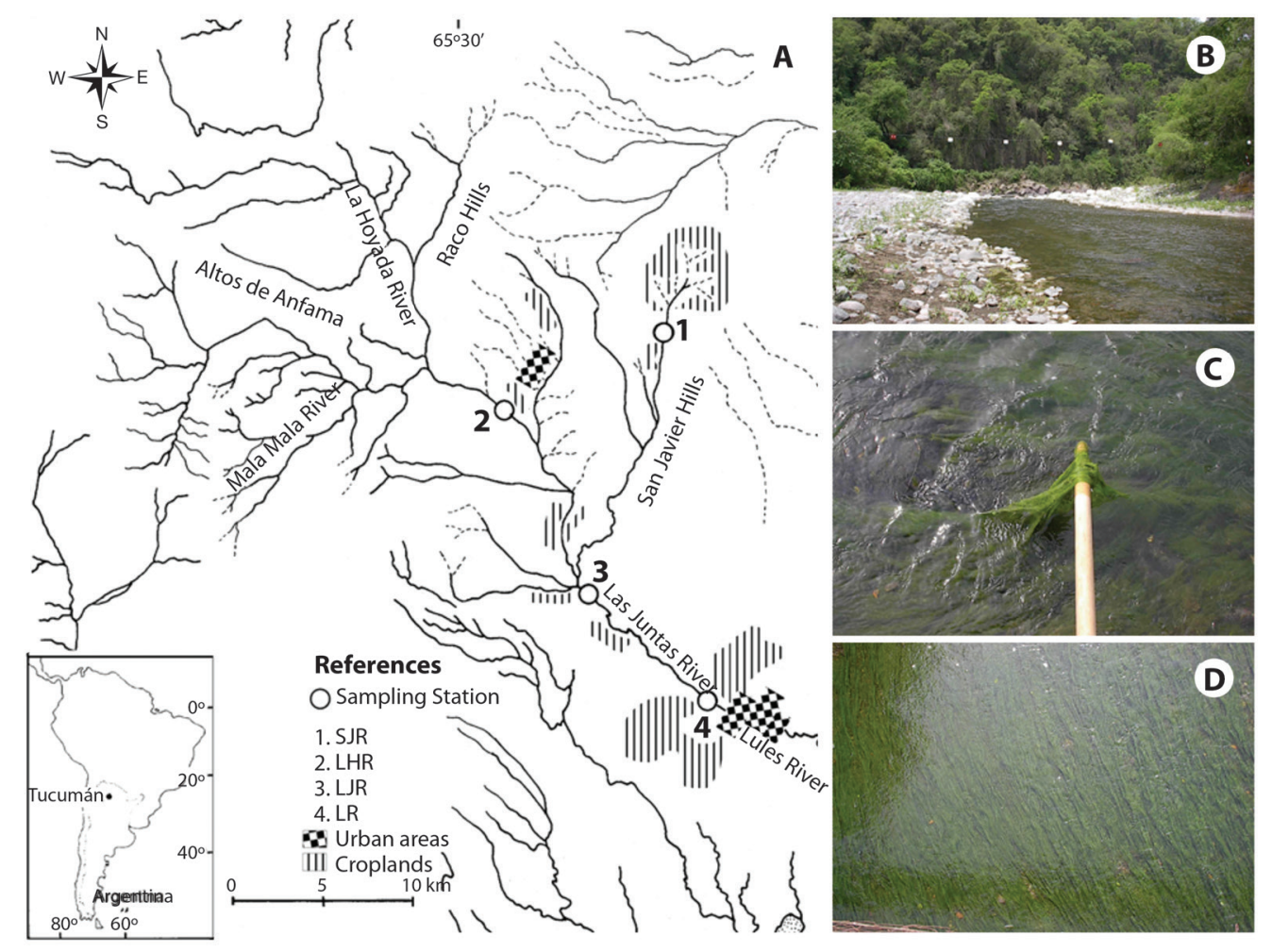

Fig. 1. (a) Map of the studied area, including locations of the sampling stations on the Lules River, and an insert of the situation of Tucuman within Argentina and South America. (b) Las Juntas River (LJR) at the beginning of the summer season (November) in this site samples with microbialites were taken. (c) Cladophora sp. filaments with microbialites during the early summer. (d) Cladophora biomass bloom (approx. $100 \%$ river bed coverage). Photograph taken from a bridge of $4 \mathrm{~m}$ high.

found (site LJR, Fig. 1b). At this point, the river has a mean width of $14.44 \mathrm{~m}$ and mean depth of $0.31 \mathrm{~m}$, with an average temperature of $21{ }^{\circ} \mathrm{C}$. EPT (Ephemeroptera, Plecoptera, Trichoptera) index classified water quality as "slightly impacted" (Fernandez et al., 2009), OM (Organic Matter) ranges between 1.10 - 9.2 $\mathrm{mg} \mathrm{L}^{-1}$, electrical conductivity ranges between $390-616 \mu \mathrm{S} / \mathrm{cm}$, and nitrate concentration varies between $2.2-4.6 \mathrm{mg} / \mathrm{L}$. The riparian buffer zone in all the studied areas is impacted by loose-roaming cattle (Quiroga, Fernandez, Sirombra, \& Dominguez, 2011).

We marked sampling stations taking into account strategic distances, and at points that offered representative examples of the variation within the river basin (Fig. 1a). We collected samples using Surber sampler (0.09 $\mathrm{m}^{2}$ with mesh size 250 microns). In each of the selected sites, we took three random samples from the riffles in all four seasons of a year (November 2003 and March, May and August 2004). We fixed the samples in the field, with a $4 \%$ solution of formaldehyde. Once free of macroinvertebrates, we dried algae samples at $100{ }^{\circ} \mathrm{C}$ and weighed them (Mettler electronic balance, accuracy $=0.01 \mathrm{~g}$ ). Samples were fixed overnight at $4{ }^{\circ} \mathrm{C}$ in a Karnovsky fixative comprising formaldehyde $(8 \% \mathrm{v} / \mathrm{v})$, glutaraldehyde $(16 \% \mathrm{v} / \mathrm{v})$ and phosphate buffer $(\mathrm{pH}$ $=7$ ). The fixed samples were washed three times with phosphate buffer and $\mathrm{CaCl}_{2}$ for 10 min, and fixed with osmium tetroxide (2\% $\mathrm{v} / \mathrm{v}$ ) overnight. Afterwards, the samples were 


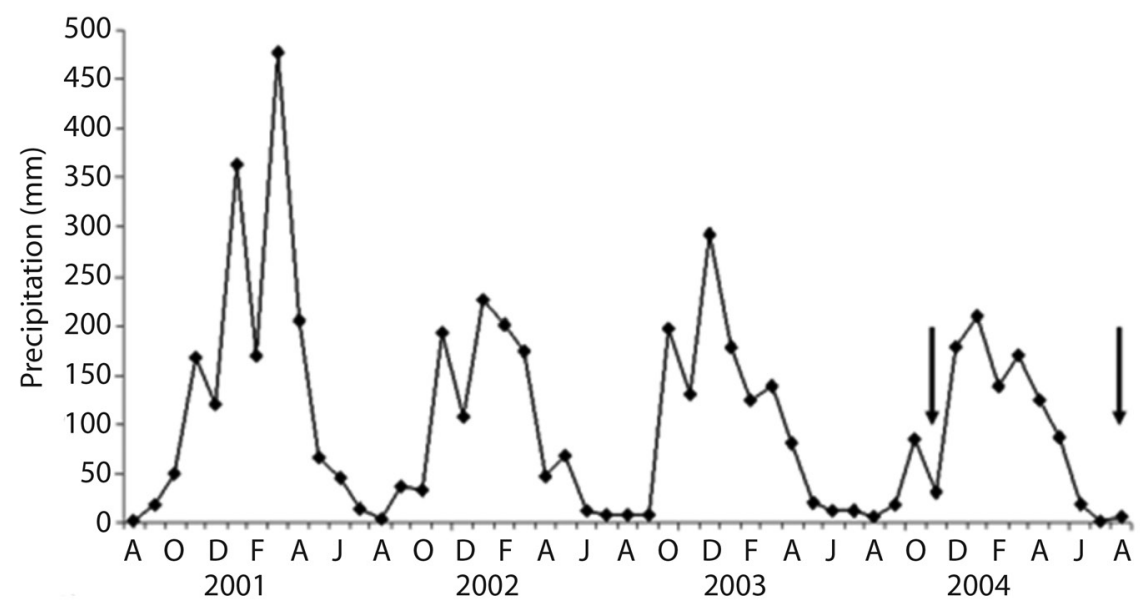

Fig. 2. Average monthly precipitation from 2000 to 2004. It should be noted that the profile for the year 2000-2001 is representative of a typical precipitation profile for this area. The total rainfall for the period 2002-2004 was lower than expected. The arrows indicate the months in which microbialites associated with Cladophora sp. filaments were found.

washed twice with ethanol $(30 \% \mathrm{v} / \mathrm{v})$ for 10 min, dried at a critical point, and sputtered with gold. Specimens were observed under vacuum using a scanning electron microscope Jeol JSM-35 (Albarracín, Winik, Kothe, Amoroso, \& Abate, 2008). We performed the X-ray diffraction analysis using a Philips based diffractometer PW 3710 (Rolandi et al., 2011).

\section{RESULTS}

In only two of the sampling campaigns (Fig. 2, arrows) we obtained attached microbialite-like structures within Cladophora sp. mats (Fig. 3, Fig. 4a, Fig. 4b, Fig. 4c and Fig. 4d). These microstructures, which varied in both size and weight (mean $=2 \mathrm{~mm}$ diameter, $0.37 \mathrm{~g}$ weight), had clearly formed cylinders around the filaments of Cladophora sp. (Fig. $4 \mathrm{~b}$ and Fig. 4c). Two mat-samples were taken in the sampling campaign of late spring 2003, and three samples during the one performed in early winter 2004 (Table 1). The relative weights of microstructures to mat were different for the two periods. In the spring, microbialite weight represented between $36.5 \%$ and

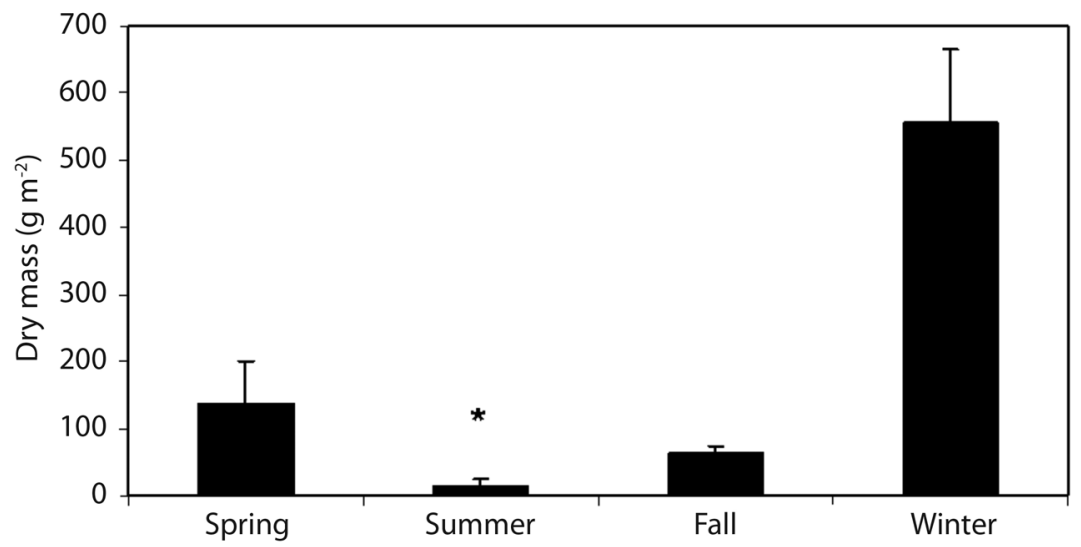

Fig. 3. Seasonal variation of Cladophora sp. weight in the Lules River: Spring $(\mathrm{N}=11)$; Summer $(\mathrm{N}=12)$; Fall $(\mathrm{N}=8)$; Winter $(\mathrm{N}=12)$. Asterisk shows significant difference ( $\mathrm{T}$ test, $\mathrm{P}<0.05)$. 

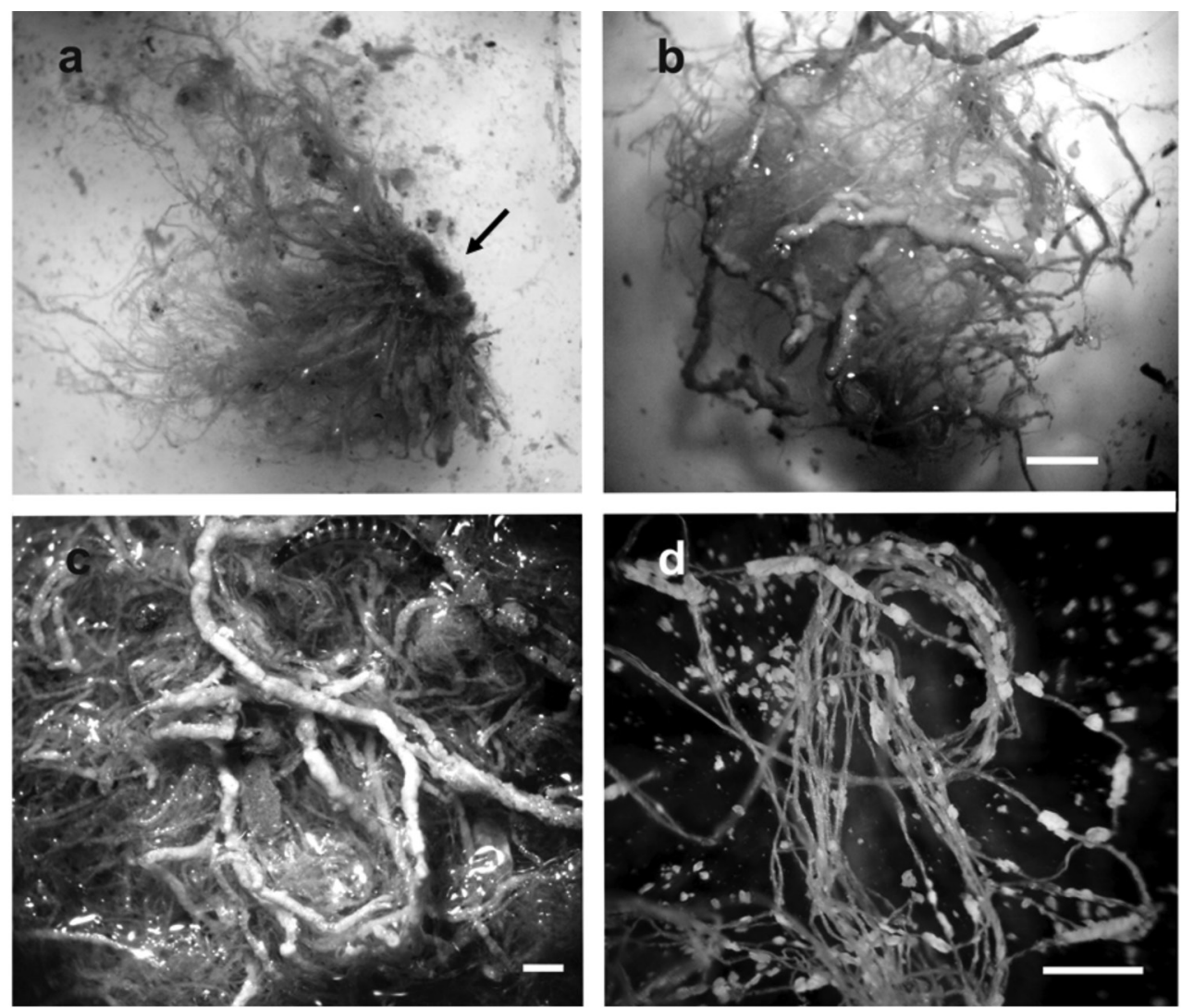

Fig. 4. Cladophora sp. mat with microbialites. (a) Unamplified photograph of a mat collected in 2003, the arrow indicates rhizoid used to attach to a rock. (b) Optical microscope image of the same mat shows the tubes of calcite around the Cladophora sp. filaments, white bar scale $=10 \mathrm{~mm}$. (c) Amplified image of a sample including a larvae of Elmidae (Insecta), white bar scale $=1.3 \mathrm{~mm}$. (d) Filaments of Cladophora sp. from sample collected in 2004, note the reduced microbialites, white bar scale $=10 \mathrm{~mm}$.

TABLE 1

Microbialites weights compared with the corresponding total dry algae mat weight. Note the large variation in the measured weights

\begin{tabular}{ccc} 
Date & Algae mat weight $(\mathrm{g})$ & Microbialite weight $(\mathrm{g})$ \\
$11-17-2003$ & 3.4 & 1.24 \\
& 0.62 & 0.52 \\
& 3.89 & 0.04 \\
$8-4-2004$ & 0.43 & 0.05 \\
& 0.46 & 0.04 \\
\hline
\end{tabular}

$83.9 \%$ of the total algae mat dry weight, while the proportion was significantly smaller in the winter samples, only representing from 1 to $11 \%$ of the total weight.

During the two consecutive abnormally dry summer seasons, we collected Cladophora sp. mats (Fig. 1c) that had an average seasonal algae biomass of $180.6 \mathrm{~g} \mathrm{~m}^{-2}$ (Fig. 1d). This value increased in winter (Fig. 3) but subsequently decreased significantly in summer ( $\mathrm{T}$ test, $\mathrm{P}<0.05)$. Nitrate content values increased from summer $\left(5.3 \mathrm{mg} \mathrm{L}^{-1}\right)$ to fall $(7.0 \mathrm{mg}$ 
$\left.\mathrm{L}^{-1}\right)$ and dropped in winter $\left(4.7 \mathrm{~m} \mathrm{~L}^{-1}\right)$. This decrease coincided with the biomass bloom of Cladophora. No significant differences (T test, $\mathrm{P}>0.05$ ) were found in the concentration of other measured nutrients, including ammonium, nitrite and phosphate.

Electron microscopy allowed to a closer analysis of the collected microstructures (Fig. 5a, Fig. 5b, Fig. 4c and Fig. 4d); numerous Gomphonema sp., which are individually stalked algae (Fig. 5c), were associated with the main filaments of the Cladophora sp., together with more typical crystals of calcite, the later confirmed by X-ray diffractometry (Fig. 6). Small quantities of quartz $\left(\mathrm{SiO}_{2}\right)$ and albite $\left(\mathrm{NaAlSi}_{3} \mathrm{O}_{8}\right)$ were also recorded. The crystals exhibited pores on their surface, presumably formed by diatom stalks (Fig. 5d).

\section{DISCUSSION}

Throughout the duration of the comprehensive 15 years research study performed on the limnology of the Lules River in Tucumán, we monitored and sampled water chemistry, precipitations and Cladophora sp. mat development (Fernandez et al., 2009; Rolandi et al., 2011). During this time, we noted interesting variations in algae biomass during a period of atypical climate patterns, occurring among 2002-2004, in which the region suffered a decrease in total annual rainfall. These dry cycles were likely related to the "El Niño" phenomenon, the phenomenon covered the period from 2000 to 2005, and its effects were observed with greater intensity in May 2002, March 2003, June 2004 and February 2005
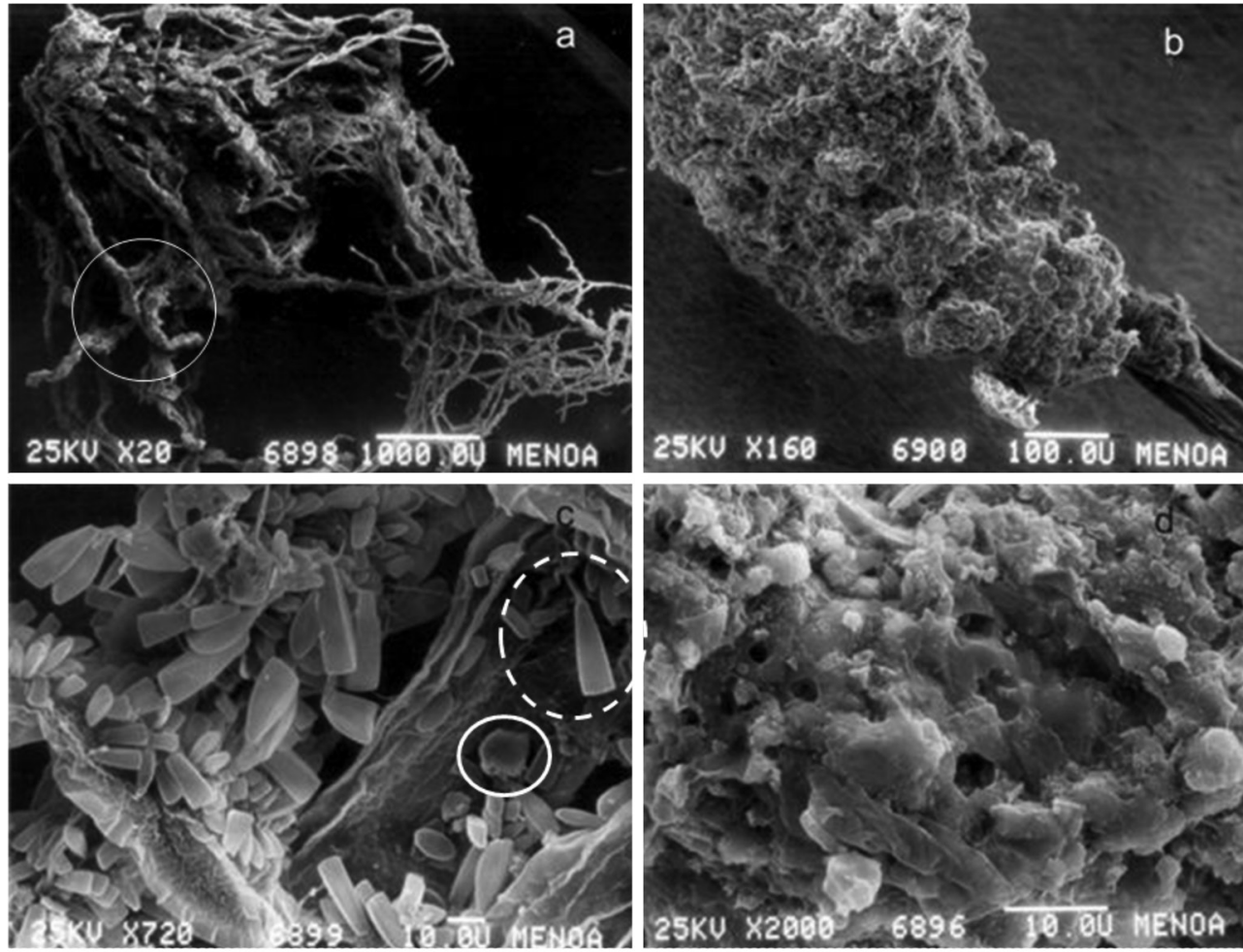

Fig. 5. Scanning electron microscope images of microbialites, amplification recorded on each slide (a) Part of a Cladophora sp. mat with calcite precipitation, rhizoid in the upper left. (b) Microbialite in detail with part of the algae filament in the lower right. (c) Detail of the stalked diatom Gomphonema sp. (dotted circle) and calcite crystal (solid circle). (d) Detail of the microbialite surface, note the pores of the surface crust. 


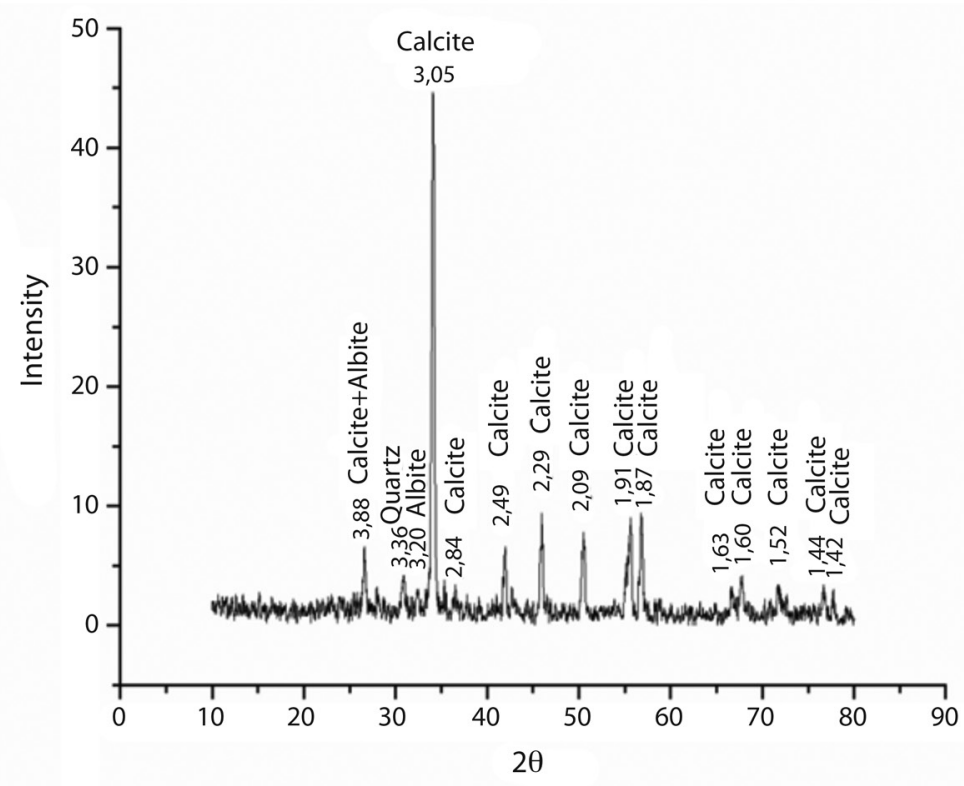

Fig. 6. Results of X-ray diffractometry, confirming the frequency of calcite (calcium carbonate) constituting microbialites.

(Fig. 2). In Northwestern Argentina, "El Niño" had the opposite effects of those observed on the pacific coast of the continent (Sayago \& Collantes, 2009).

It is clear that spring conditions in this subtropical area (relatively high temperatures caused by intense solar exposure accompanied by the absence of rainfall) favor the precipitation of calcium around the filaments of the mats. Similarly, Sabater (2000) has shown the relationship of microbialite growth to high temperature and soluble major ionic water content. In addition to temperature, increased light exposure is likely responsible for the abundant formation of these microstructures as the mechanism that initiates calcium precipitation is linked to photosynthetic metabolic activity (Sabater, Guasch, Romani, \& Muñoz, 2000).

Rivers in the province of Tucuman are characterized by important variations in soluble ion concentration due to the influence of complex geological processes (Fernandez \& Hidalgo, 2011). Sylvestre, Servant-Vildary, \& Roux (2001) established definitive relationships between the ionic composition of water and diatom community structure. The study demonstrated that the species of Gomphonema found at the altiplano (region of plateau with average altitude of 4000 m.a.s.1) lakes of Bolivia prefer calcic waters. Our results confirm these previously observed diatom assemblages.

In these eutrophic or oligotrophic conditions, the rise in $\mathrm{pH}$ levels would also increase the likelihood of carbonate precipitation during an algae bloom (Winsborough \& Golubic, 1987) while the observed decrease in total annual rainfall would assist in the generation of microbialites. Dodds and Gudder (1992) noted that in conditions of sufficient solar exposure, such as are present in the studied area, the competition for light decrease between epiphytes and Cladophora. Although there is some calcium carbonate precipitation found as a thin film on river rocks, the fact that complex structures such as microbialites are only present in Cladophora sp. lead us to believe that Gomphonema plays the main role in the precipitation of calcium carbonate, as observed by Winsborough and Golubic (1987).

The influence of environmental conditions as well as the ionic composition of the water in the ecosystem must also be considered. 
An interesting model proposed by Yates (1996) proposes that calcification occurs as cells absorb $\mathrm{CO}_{2}$. A portion of the $\mathrm{CO}_{2}$ diffuses back out of the cell, where it hydrates to $\mathrm{HCO}_{3}{ }^{-} / \mathrm{CO}_{3}{ }^{2-}$, thereby providing a source of inorganic carbon for calcite precipitation. According to McConnaughey (1994), $\mathrm{pH}$ and $\mathrm{Ca}$ are increased as $\mathrm{Ca}^{2+}$-ATPase exchanges $2 \mathrm{H}^{+}$for $\mathrm{Ca}^{2+}$ while divalent cations are pumped into the mineralizing medium at the expense of ATP. The area around the cell absorbs $\mathrm{CO}_{2}$ and releases more protons due to the reaction $\mathrm{Ca}^{2+}+\mathrm{CO}_{2}+\mathrm{H}_{2} \mathrm{O}=\mathrm{CaCO}_{3}+2 \mathrm{H}^{+}$, which are then exchanged for more $\mathrm{Ca}^{2+}$. That being said, the influence of ATPase on the precipitation indicates that the cell in some way controls the precipitation of calcite. We observed that the amount of lithified calcite on Cladophora sp. mats in the study area was related to rainfall in the region and associated climatic phenomena. To the above we can add that downstream, rivers of the same basin suffer impacts from industries that increase the concentration of organic matter in the water. This increase consequently leads to a decrease in available dissolved oxygen and a decrease of abundance in the community of microorganisms. There is a change in the balance of solubility of calcite in water contaminated with organic matter (Rolandi et al., 2011).

Dry climate cycles- probably related to "El Niño" phenomenon- alter environmental conditions such as ionic solubility equilibrium in streams. This situation necessarily drives to a new equilibrium of ions proportions. Filamentous algal blooms, sufficient solar exposure, and presence of epiphytes interact with the ionic equilibrium making special conditions at microhabitat level. Those conditions are capable of precipitating calcium carbonate when $\mathrm{pH}$ rises during an algae bloom. The releases of extracellular polysaccharides on the Gomphonema sp. stalk, around the filaments of Cladophora sp. also contribute to produce the observed calcified microaggregates that we consider as incipient microbialites-like structures. We hypothesize that these stracs observed around the filaments of Cladophora sp. are produced by the release of extracellular polysaccharides on the Gomphonema sp. stalk, as previously noted by Winsborough \& Golubic (1987). Because the lithification of calcite is affected by organic contaminants, samples of Cladophora sp. could be used as sensitive indicators of the increase of organic pollution in rivers of the region.

Ethical statement: authors declare that they all agree with this publication and made significant contributions; that there is no conflict of interest of any kind; and that we followed all pertinent ethical and legal procedures and requirements. A signed document has been filed in the journal archives.

\section{ACKNOWLEDGMENTS}

The Institute of "Estratigrafía y Geología Sedimentaria Global" (IESGLO) of Fundación Miguel Lillo, provided X-ray analysis and Centro Integral de Microscopía Electrónica (CIME, CONICET-UNT) provided SEM facilities. Particular thanks are due to Barbara M. Winsborough for her collaboration and recommendations, F. Romero for her enthusiastic assistance in the field, M. L. Rolandi for the explanation of solubility equilibrium models and M. L. Gultemirian for helping with biochemical models to explain cellular process. In addition, we extend thanks to X. Ovando for assisting us with the photography. This research was supported in part by grant \# 26/ G416 from Universidad Nacional de Tucuman. H. R. F. and V. H. A. are staff scientists from the National Research Council of Science and Technology in Argentina (CONICET).

\section{RESUMEN}

Estructuras de tipo microbialito en Cladophora sp. (Ulvophyceae) de una cuenca andina subtropical: implicaciones ecológicas. La fase sólida de las sales de los cuerpos de agua juega un papel importante en la concentración de los elementos mayoritarios. El equilibrio de solubilidad de la calcita está influenciado por factores fisicoquímicos, climáticos y biológicos. Los ciclos anuales de sequía excepcionalmente prolongada, junto con la 
contaminación orgánica difusa de origen natural, generan condiciones únicas para la precipitación de estructuras de carbonato litificado (microbialitos). El objetivo de este artículo es analizar las posibles implicaciones de la precipitación de calcita producida en Cladophora sp. en una cuenca subtropical andina, considerando que es la primera vez que se describe este fenómeno para la región. Recolectamos muestras en sitios seleccionados en la Cuenca del Río Lules, en cuatro fechas de muestreo entre 2003 y 2004, en el marco de un trabajo de monitoreo de quince años. Usamos red Surber para realizar los muestreos. Las muestras de algas, una vez libres de macroinvertebrados, se secaron y pesaron. Analizamos utilizando microscopía electrónica y difracción de rayos X. Encontramos que Gomphonema sp. unido a Cladophora contribuye a la precipitación de calcita y la formación de estructuras similares a microbialitos, en el área estudiada. Este trabajo presenta una discusión inicial sobre el descubrimiento de estructuras similares a microbialitos unidas a filamentos de Cladophora sp. en una cuenca andina subtropical y las condiciones ambientales que conducen a su producción, así como las posibles implicaciones ecológicas de lo mencionado anteriormente.

Palabras clave: carbonato litificado; diatomeas; epífitas; ciclos climáticos secos.

\section{REFERENCES}

Albarracín, V. H., Winik, B., Kothe, E., Amoroso, M. J., \& Abate, C. M. (2008). Copper bioaccumulation by the actinobacterium Amycolatopsis sp. AB0. Journal of Basic Microbiology, 48, 323-330.

Burne, R. V., \& Moore, L. S. (1987). Microbialites: organosedimentary Deposits of Benthic Microbial Communities. Palaios, 2, 241-254.

Chafetz, H., Rush, P. F., \& Utech, N. M. (1991). Microenvironmental controls on mineralogy and habit of $\mathrm{CaCO}_{3}$ precipitates: an example from an active travertine system. Sedimentology, 38(1), 107-126.

Dittrich, M., \& Obst, M. (2004). Are Picoplankton Responsible for Calcite Precipitation in Lakes? Ambio, $33,559-564$.

Dodds, W. K. (1991). Micro-environmental characteristics of filamentous algal communities in flowing freshwaters. Freshwater Biology, 25, 199-209.

Dodds, W. K., \& Gudder, D. A. (1992). The ecology of Cladophora. Journal of Phycology, 28, 415-427.

Fernandez, D. S., \& Hidalgo, M. del V. (2011). Análisis geoquímico ambiental de la cuenca del río Lules mediante el uso de muestras de sedimentos de corriente. In H. R. Fernández, \& H. Barber (Eds.), La cuenca del río Lules: una aproximación multidisciplinaria a su complejidad (pp. 33-46). Tucuman, Argentina: Edunt.
Fernández, H. R., \& Reid, B. (2012). Invertebrate distribution on a macroalgae/macrophyte mixed mat in flowing water. Fundamental and Applied Limnology, 181, 289-299.

Fernandez, H. R., Romero, F., \& Domínguez, E. (2009). Intermountain basins uses in a subtropical region and their influence on benthic fauna. River Research and Applications, 25, 181-193.

Garcia, A. K. (2010). Cambios en la cobertura y estado ambiental, de la cuenca del río Lules (TucumánArgentina) (Master's thesis). Universidad Nacional de Tucumán, Tucumán, Argentina.

Kwong, E., Salas, R., Gutiérrez, E., \& López, F. (Agosto, 2004). Distribución del oxígeno disuelto, pH y temperatura de la laguna facultativa de la planta Maracaibo Sur. In Congreso Interamericano de Ingeniería Sanitaria y Ambiental XXIX. Congreso llevado a cabo por Asociación Interamericana de Ingeniería Sanitaria y Ambiental (AIDIS), Puerto Rico.

McConnaughey, T. A. (1994). Past and present biomineralization processes. Bulletin of the Institute of Oceanography, 13, 137-162.

Mesa, L. M. (2006). Morphometric analysis of a subtropical Andean basin (Tucumán, Argentina). Environmental Geology, 50, 1235-1242.

Mesa, L. M., Fernandez, H. R., \& Manzo, M. V. (2009). Seasonal patterns of Benthic Arthropods in a Subtropical Andean Basin. Limnologica, 39, 152-162.

Quiroga, P. A., Fernandez, H. R., Sirombra, M. D., \& Domínguez, E. (2011). Riparian forests and cattle management problems in Andean subtropical streams: in the search of water quality sustainability. Lilloa, 48, 32-52.

Rolandi, M. L., Galindo, M. C., Fernandez, H. R., \& Hidalgo, M. del V. (2011). Equilibrios de solubilidad en la cuenca media del río Lules. In H. R. Fernández, \& Barber, H. (Eds.), La cuenca del río Lules: una aproximación multidisciplinaria a su complejidad (pp. 47-59). Tucuman, Argentina: Edunt.

Romani, A. M., \& Sabater, S. (1998). A stromatolitic cyanobacterial crust in a Mediterranean stream optimizes organic matter use. Aquatic Microbial Ecology, 16, 131-141.

Sabater, S. (2000). Structure and architecture of a stromatolite from a Mediterranean stream. Aquatic Microbial Ecology, 21, 161-168.

Sabater, S., Guasch, H., Romaní, A., \& Muñoz, I. (2000). Stromatolitic communities in Mediterranean streams: conditions to a changing environment. Biodiversity and Conservation, 9, 379-392.

Sandgren, C. D., Engevold, P. M., Neerhof, S., \& Ehlinger, T. J. (2004). Nuisance Cladophora in Urban 
Streams: habitats, seasonality, morphology, production, nutrient composition, heavy metals, foodweb bottleneck. Cladophora Research and Management in the Great Lakes, 43.

Sayago, J. M., \& Collantes, M. M. (2009). ¿Cambio climático o cambio geomorfodinámico? In J. M. Sayago, \& M. M. Collantes (Eds.), Geomorfología y cambio climático (pp. 9-24). Tucuman, Argentina: Magna Ediciones.

Sylvestre, F., Servant-Vildary, S., \& Roux, M. (2001). Diatom-based ionic concentration and salinity models from the south Bolivian Altiplano (15 - $\left.23^{\circ} \mathrm{S}\right)$. Journal of Paleolimnology, 25, 279-295.

Trimborn, S., Lundholm, N., Thoms, S., Richter, K. U., Krock, B., Hansen, P. J., \& Rost, B. (2008). Inorganic carbon acquisition in potentially toxic and non-toxic diatoms: the effect of $\mathrm{pH}$-induced changes in seawater carbonate chemistry. Physiologia Plantarum, 133(1), 92-105.

Weiner, S., \& Dove, P. M. (2003). An overview of biomineralization processes and the problem of the vital effect. Review of Mineral Geochemistry, 54, 1-29.

Winsborough, B. M. (2000). Diatoms and Benthic Microbial Carbonates. In R. E. Riding, \& S. M. Awramik (Eds.), Microbial Sediments (pp. 76-83). Berlin, Germany: Springer-Verlag.

Winsborough, B. M., \& Golubic, S. (1987). The role of Diatoms in stromatolite growth: two examples from modern freshwater settings. Journal of Phycology, 23, 195-201.

Yates, K. K. (1996). Microbial Precipitation of Calcium Carbonate: a Potential Mechanism for Lime-mud Production (Doctoral dissertation). University of South Florida, South Florida, USA. 